\title{
Antithrombotic selection and risk factor management in ischemic stroke and transient ischemic attack
}

\author{
Brian S. Katz, M.D., and Kelly D. Flemming, M.D. \\ Department of Neurology, Mayo Clinic College of Medicine, Rochester, Minnesota
}

\begin{abstract}
In addition to appropriate antithrombotic therapy, the identification and treatment of modifiable ischemic stroke risk factors can reduce the likelihood of recurrent stroke. Neurosurgeons should be knowledgeable of the specific risk factors and general recommendations for ischemic stroke, as they may play a significant role in the management options for patients with intracranial and extracranial atherosclerotic disease. The authors of this article review the indications for and selection of antithrombotics in patients with cerebral ischemia. In addition, the identification and secondary prevention of select risk factors are discussed.

(http://thejns.org/doi/abs/10.3171/2013.10.FOCUS13402)
\end{abstract}

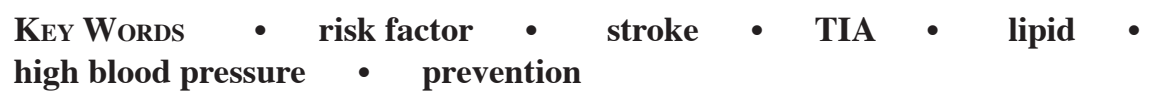

$\mathrm{S}$ TROKE is the fourth leading cause of death in the United States and is a leading cause of disability. In addition to selecting the appropriate antithrombotic, the identification and treatment of modifiable stroke risk factors can reduce the likelihood of first or recurrent stroke, prevent long-term morbidity and mortality after the first stroke or transient ischemia attack (TIA), and lower health care costs..$^{19,49,60,65}$ While preventing recurrent cerebral ischemia is the obvious target of secondary stroke prevention, additional goals include averting other vascular disease (for example, myocardial infarction) and identifying and heading off other medical complications of cerebral ischemia (for example, depression, infection, deep vein thrombosis).

The focus of this paper is the secondary prevention of ischemic stroke or TIA. A broad overview of the indication for and selection of antithrombotics is provided. In addition, common ischemic stroke risk factors and the impact of each factor, how to diagnose it, and management for secondary prevention are reviewed. We conclude with practical information for assessing and treating risk factors.

Abbreviations used in this paper: $\mathrm{AHA}=$ American Heart Association; $\mathrm{A} 1 \mathrm{C}=$ glycated hemoglobin; $\mathrm{CPAP}=$ continuous positive airway pressure; $\mathrm{HDL}=$ high-density lipoprotein; INR = international normalized ratio; LDL = low-density lipoprotein; OSA = obstructive sleep apnea; PSG = polysomnography; TIA = transient ischemic attack.

\section{Applicability to Neurosurgery}

Neurologists and/or internists typically manage risk factors associated with cerebral ischemia. However, a practicing neurosurgeon can benefit from a broad understanding of cerebrovascular risk factors and antithrombotic indications for several reasons. Patients with carotid artery disease, for instance, may be hospitalized solely on a neurosurgical service; thus, knowledge of the proper treatment of this patient beyond daily aspirin can be useful. Another example would be a neurosurgeon consulted on a patient with intracranial atherosclerosis. Endovascular treatment may be indicated when patients are "maximally" medically treated. Knowledge of what this means beyond antithrombotics may help the neurosurgeon decide whether further medical management or endovascular treatment is indicated. Finally, many patients undergoing neurosurgical procedures have cerebrovascular disease, and knowledge of the risk factors may help in the general management of these patients to help minimize perioperative ischemic stroke.

\section{Indications for and Selection of Antithrombotics}

\section{Indications}

Antithrombotics are indicated in most cerebral ischemic mechanisms or etiologies. The important distinction is whether the mechanism of cerebral ischemia requires an 
antiplatelet agent or an anticoagulant (Table 1). Antiplatelet agents are indicated in most noncardioembolic etiologies of cerebral ischemia. Anticoagulants are indicated in patients with cerebral ischemia and one of the following cardioembolic etiologies: atrial fibrillation, left ventricular or left atrial thrombus, mechanical heart valve, and recent anterior wall myocardial infarction with left ventricular thrombus. Anticoagulation is also recommended in phospholipid antibody syndrome, ${ }^{54}$ although it is not indicated for antiplatelet agent failure. ${ }^{47,88,122}$

There are limited data regarding the most appropriate antithrombotic in patients with an extracranial arterial dissection and cerebral ischemia. Current American Heart Association (AHA) guidelines for the secondary prevention of ischemic stroke and TIA $^{54}$ suggest that an antiplatelet or anticoagulant agent is acceptable treatment. Similarly, there are conflicting data regarding the use of an antiplatelet agent or anticoagulation in patients with cardiomyopathy; ${ }^{54}$ however, a recent substudy of the Warfarin versus Aspirin in Reduced Cardiac Ejection Fraction trial $^{103}$ observed less cardioembolic ischemic stroke in the warfarin arm compared with the aspirin arm. The overall stroke rate, including all mechanisms of cerebral ischemia between the two groups, was not statistically significant.

\section{Antiplatelet Agents}

Antiplatelet agent choices for cerebral ischemia include aspirin (50-325 mg daily), clopidogrel (75 mg daily), or the combination of extended-release dipyridamole $(200 \mathrm{mg})$ and aspirin $(25 \mathrm{mg})$ twice daily. According to multiple clinical trials and the AHA guidelines, any of these three options is considered appropriate monotherapy for cerebral ischemia (Table 2).$^{54}$ Based on the second Cilostazol Stroke Prevention Study (CSPS 2), ${ }^{119}$ cilostazol may be a reasonable alternative as well, as it was noninferior to aspirin.

In clinical practice, the selection of an antiplatelet agent depends on multiple factors: cost, compliance (once- vs twice-daily dosing), side effects, interactions (for example, proton pump inhibitors and clopidogrel), and comorbidities. While no trial has studied only patients in whom aspirin has failed, it is common clinical practice to choose an alternative and/or to maximize risk factor treatment.

Prasugrel is contraindicated in cerebral ischemia. In a recent coronary artery disease trial, prasugrel was associated with a higher bleeding risk, especially in patients with prior cerebrovascular disease. ${ }^{135}$ There are limited efficacy and safety data on cerebral ischemia patients taking the newer antiplatelet agents such as the direct P2Y12 antagonists (ticagrelor and elinogrel) and the proteaseactivated receptor antagonists (vorapaxar and atopaxar). There are limited data on the thromboxane receptor antagonists (terutroban and picotamide); however, they appear to be equivalent to aspirin at this time.

\section{Combination of Aspirin and Clopidogrel}

In general, the combination of aspirin and clopidogrel in the long term has not proven more efficacious than monotherapy in patients with cerebral ischemia, ${ }^{12,14,42}$ and the combination is not recommended unless there is another indication such as a carotid or coronary stent. ${ }^{54}$ However, there are evolving data regarding the potential short-term benefit of the combination.

The Clopidogrel and Aspirin for Reduction of Emboli in Symptomatic Carotid Stenosis (CARESS) ${ }^{86}$ study randomized patients with recently symptomatic carotid artery stenosis to aspirin and clopidogrel versus aspirin monotherapy. The results demonstrated a significant reduction in asymptomatic microembolic signals on transcranial Doppler ultrasonography in patients on the combination therapy versus aspirin alone. While the study was not powered to look at clinical outcomes, the rate of recurrent stroke was lower with combination therapy than with aspirin alone.

While the Stenting vs. Aggressive Medical Management for Preventing Recurrent Stroke in Intracranial Stenosis (SAMMPRIS) study was not designed to specifically assess medical management strategies, ${ }^{26}$ the lower than expected risk of recurrent cerebral ischemia in the medical arm compared with that in the Warfarin-Aspirin Symptomatic Intracranial Disease (WASID) ${ }^{27}$ study was attributed in part to the antithrombotics and close attention to risk factor management in the SAMMPRIS study.

Recently the Clopidogrel in High-Risk Patients with Acute Nondisabling Cerebrovascular Events (CHANCE) $)^{130}$ study demonstrated that the combination of clopidogrel and aspirin was superior to aspirin alone for reducing stroke risk at 90 days in patients with TIA or minor stroke treated within 24 hours of symptom onset. The combination therapy was used for the first 21 days, followed by clopidogrel alone for the remaining 90-day period, which did not result in excess hemorrhage.

At present, no guidelines indicate when and in what patients the short-term combination of aspirin and clopidogrel should be used. Additional data from the Plate-

TABLE 1: Selection of antithrombotics by etiology of cerebral ischemia

\begin{tabular}{lll}
\hline \multicolumn{1}{c}{ Antiplatelet Agent } & \multicolumn{1}{c}{ Anticoagulant } & Conflicting or Absent Data† \\
\hline $\begin{array}{l}\text { carotid artery atherosclerosis } \\
\text { intracranial atherosclerosis }\end{array}$ & $\begin{array}{l}\text { atrial fibrillation } \\
\text { mechanical heart valve } \\
\text { lacunar disease }\end{array}$ & $\begin{array}{l}\text { arterial dissection } \\
\text { cardiomyopathy }\end{array}$ \\
cryptogenic stroke & phospholipid antibody syndrome & \\
\hline * Most noncardioembolic strokes require an antiplatelet agent. An exhaustive list of all causes in this table was not possible. \\
$\dagger$ Current guidelines suggest that either an antiplatelet agent or anticoagulation is acceptable therapy. Data are either lacking or \\
conflicting in these areas.
\end{tabular}




\section{Risk factor management}

TABLE 2: Selected antiplatelet agent trials for the secondary prevention of cerebral ischemia*

\begin{tabular}{|c|c|c|c|}
\hline Clinical Trial† & Agent Assessed & Primary End Point & Results \\
\hline $\begin{array}{l}\text { Antiplatelet Trialists' } \\
\text { Collaborative }^{7}\end{array}$ & aspirin (30-1600 mg daily) versus placebo & $\begin{array}{l}\text { stroke, myocardial infarc- } \\
\text { tion, or vascular death }\end{array}$ & $\begin{array}{c}\text { for stroke patients, aspirin reduced risk of stroke by } \\
4 \%(18 \% \text { aspirin vs } 22 \% \text { control; } 2 p<0.00001)\end{array}$ \\
\hline CAPRIE $^{25}$ & $\begin{array}{l}\text { aspirin (325mg) versus clopidogrel ( } 75 \mathrm{mg} \\
\text { daily) }\end{array}$ & $\begin{array}{l}\text { stroke, myocardial infarc- } \\
\text { tion, or vascular death }\end{array}$ & $\begin{array}{l}\text { in overall group (myocardial infarction, peripheral vas- } \\
\text { cular disease, stroke), the risk of vascular out- } \\
\text { comes was } 5.83 \% \text { w/ aspirin versus } 5.32 \% \mathrm{w} / \\
\text { clopidogrel }(p=0.043)\end{array}$ \\
\hline ESPS-2 $2^{43}$ & $\begin{array}{l}\text { placebo versus aspirin ( } 25 \mathrm{mg} \text { BID) versus } \\
\text { extended-release dipyridamole ( } 200 \mathrm{mg} \\
\text { BID) versus aspirin }(25 \mathrm{mg}) \text { \& extended- } \\
\text { release dipyridamole }(200 \mathrm{mg}) \text { BID }\end{array}$ & stroke or death & $\begin{array}{l}\text { combination of dipyridamole \& aspirin resulted in } \\
9.5 \% \text { recurrent stroke versus } 12.4 \% \text { in the aspirin- } \\
\text { alone group ( } p=0.006 \text { ) }\end{array}$ \\
\hline PRoFESS ${ }^{113}$ & $\begin{array}{l}\text { clopidogrel ( } 75 \mathrm{mg} \text { daily) versus extended- } \\
\text { release dipyridamole }(200 \mathrm{mg}) \& \text { aspirin } \\
(25 \mathrm{mg}) \text { BID }\end{array}$ & first recurrence of stroke & $\begin{array}{l}\text { no significant difference in first recurrence of stroke } \\
\text { ( } 9.0 \% \text { aspirin-dipyridamole combination vs } 8.8 \% \\
\text { clopidogrel) }\end{array}$ \\
\hline
\end{tabular}

* $\mathrm{BID}=$ twice a day; $\mathrm{CAPRIE}$ = clopidogrel versus aspirin in patients at risk of ischaemic events; ESPS-2 = European Stroke Prevention Study 2; PRoFESS $=$ Prevention Regimen For Effectively Avoiding Second Strokes .

$\dagger$ Superscripted numbers represent reference numbers.

let Oriented Inhibition in New TIA and Minor Ischemic Stroke (POINT) trial is expected to help further elucidate selection.

\section{Anticoagulation}

Data from numerous clinical trials support the use of warfarin (goal INR 2-3) over an antiplatelet agent (aspirin or the combination of aspirin and clopidogrel) in patients with atrial fibrillation. ${ }^{54}$ Emerging options for nonvalvular atrial fibrillation include novel anticoagulants such as dabigatran, rivaroxaban, and apixaban. These agents are described in more detail below under Atrial Fibrillation.

\section{Overview of Ischemic Stroke Risk Factors}

A number of definitive and putative risk factors predict the first ischemic stroke (Table 3). The most common major risk factors include hypertension, hyperlipidemia, tobacco use, and diabetes. Overall target goals for the secondary prevention of these major risk factors are noted in Table 4 and reviewed in more detail below.

\section{Hypertension}

Risk. High blood pressure is a risk factor for ischemic stroke as well as intracerebral hemorrhage, subarachnoid hemorrhage, and aneurysm formation. The risk of vascular complications and death begins to rise when blood pressure exceeds 115/75 $\mathrm{mm} \mathrm{Hg.}{ }^{79}$ Elevated blood pressure may contribute to cerebral ischemia through its effects on small and large blood vessels (lipohyalinosis and atherosclerosis) and by contributing to cardiac disease and dysfunction.

The incidence of stroke increases in proportion to both diastolic and systolic blood pressure. It is important to recognize, however, that elevated systolic blood pressure with or without elevated diastolic blood pressure is a risk factor. The relationship between blood pressure and risk of ischemic events (stroke and myocardial infarction) is continuous and independent of other risk factors. For each increment of $20 \mathrm{~mm} \mathrm{Hg}$ in systolic or $10 \mathrm{~mm} \mathrm{Hg}$ in diastolic blood pressure, the risk of cardiovascular disease doubles over the entire range from 115/75 to 185/115 $\mathrm{mm} \mathrm{Hg}$ in patients aged $40-70$ years. ${ }^{28}$

Diagnosis. Blood pressure in the acute setting after ischemic stroke or TIA is almost always elevated. ${ }^{1}$ While there is no definitively established time frame in which to treat blood pressure more aggressively, ${ }^{1,94}$ we typically wait at least 2-4 weeks after an ischemic event, a time frame consistent with many long-term secondary prevention trials and improvement in the impaired autoregulatory curve.

Once a patient is beyond the acute phase, blood pressure can be assessed and, if elevated, gradually lowered toward goal. Blood pressure can be measured in the office, at home, or via ambulatory monitoring. The latter method of monitoring can be useful in patients with "white coat hypertension," blood pressure resistant to treatment, or episodic hypotension. If one bases the reading on an office reading, blood pressure should be mea-

\section{TABLE 3: Risk factors for first ischemic stroke}

\begin{tabular}{ll}
\hline \multicolumn{1}{c}{ Definitive } & \multicolumn{1}{c}{ Putative } \\
\hline $\begin{array}{l}\text { hypertension } \\
\text { dyslipidemia }\end{array}$ & impaired fasting glucose \\
diabetes & metabolic syndrome \\
tobacco smoking & alcohol abuse \\
asymptomatic carotid disease & drug abuse \\
atrial fibrillation & hypercoagulability \\
obesity & inflammatory processes \\
physical inactivity & obstructive sleep apnea \\
hormone replacement therapy \& oral & \\
$\quad$ contraceptive use & \\
sickle cell anemia & \\
\hline
\end{tabular}


B. S. Katz and K. D. Flemming

TABLE 4: Secondary prevention goals for major risk factors*

\begin{tabular}{|c|c|c|c|}
\hline Risk Factor & Goal & ARR w/ Treatment & RRR w/ Treatment $†$ \\
\hline hypertension & $<140 / 90 \mathrm{~mm} \mathrm{Hg}$ & w/ reduction by $12 / 5 \mathrm{~mm} \mathrm{Hg} 6 \%$ & $43 \% 101$ \\
\hline hyperlipidemia & $\mathrm{LDL}<70 \mathrm{mg} / \mathrm{dl} \neq$ & $\begin{array}{l}2.2 \% \text { cerebrovascular (SPARCL trial§), } \\
\quad 3.5 \% \text { cardiovascular }\end{array}$ & $\begin{array}{l}16 \% \text { cerebrovascular, } 18 \% \text { cardio- }^{\text {vascular }^{3}}\end{array}$ \\
\hline blood sugar & $<100 \mathrm{mg} / \mathrm{dl}$ (fasting) & - & - \\
\hline diabetes & $\mathrm{A} 1 \mathrm{C}<7 \% \Phi$ & - & - \\
\hline tobacco & cessation & - & $50 \%{ }^{132} \boldsymbol{q}$ \\
\hline
\end{tabular}

* $A R R$ = absolute risk reduction; $L D L=$ low-density lipoprotein; $R R R=$ relative risk reduction; SPARCL = Stroke Prevention by Aggressive Reduction in Cholesterol Levels.

† Superscripted numbers represent reference numbers.

$\ddagger$ In those with cerebral ischemia and atherosclerosis or coronary artery disease or coronary artery disease "equivalent."

$\S$ SPARCL used a fixed dose of $80 \mathrm{mg}$ of atorvastatin rather than an LDL goal.

II Primary prevention study.

sured at least twice, with 2 minutes between each reading and a proper technique (appropriate cuff size, positioning, cuff placement, and setting). An average blood pressure greater than $140 / 90 \mathrm{~mm} \mathrm{Hg}$ is considered elevated. ${ }^{28,54}$ Some recent studies have suggested that interindividual variation (visit to visit variation) may be more important than the average blood pressure. ${ }^{110,133}$

Treatment. Before treating blood pressure in a patient who has had cerebral ischemia, several precautions are in order. Blood pressure in the acute setting is often elevated in response to preserve collateral flow to the penumbra. Thus, as noted above, in secondary prevention, blood pressure is assessed and gradually lowered toward goal beginning at least 2-4 weeks after the event. Prior to aggressive treatment, one must be careful about applying a "one size fits all" blood pressure goal. For example, a patient with critical intracranial stenosis may need higher than normal blood pressure if he or she is prone to recurrent episodes of hypoperfusion. A final note: some patients may have secondary causes of elevated blood pressure and require treatment of the underlying condition rather than the increased blood pressure. For example, nonsteroidal antiinflammatory medications are commonly prescribed medications and can elevate blood pressure. In addition, unrecognized sleep apnea can make blood pressure resistant to treatment. Other secondary causes of elevated blood pressure are noted in Table 5.

An essential tactic for treating hypertension is lifestyle modification, which may include weight control; a diet rich in fruits, vegetables, and low-fat dairy products; regular aerobic physical activity; limited alcohol consumption; and moderation in sodium intake..$^{20,54}$

Several trials have strongly indicated that long-term treatment of hypertension reduces the relative risk of either initial or recurrent stroke. ${ }^{39,99,101,128,140,142}$ Clinical trials have evaluated diuretics, ${ }^{2,39,99,101}$ beta blockers, ${ }^{103,133}$ angiotensin-converting enzyme inhibitors, ${ }^{82,101,141}$ angiotensin receptor blockers, ${ }^{39,140}$ and calcium channel blockers ${ }^{70,110}$ in stroke prevention. The evidence is conflicting, making no compelling case for one agent over others for secondary stroke prevention. The one exception may be beta blockers, which may not reduce stroke recurrence as well as calcium channel blockers, angiotensin inhibitors, and even placebo in some trials..$^{10,11,61,133,136}$

What we can conclude from multiple clinical trials is that the lowering of blood pressure, not individual classes of medication, is beneficial. In secondary prevention trials, a reduction in blood pressure by $12 / 5 \mathrm{~mm} \mathrm{Hg}$ was associated with a relative risk reduction of approximately $43 \% .{ }^{101}$ Medications should be selected based on patient comorbidities, preferences, and tolerances. ${ }^{54}$

The goal blood pressure has not been definitively established in clinical trials. Current AHA guidelines for the secondary prevention of ischemic stroke recommend following "The Seventh Report of the Joint National Committee on Prevention, Detection, Evaluation, and Treatment of High Blood Pressure" (JNC7) guideline of a goal blood pressure $<140 / 90 \mathrm{~mm} \mathrm{Hg}$. While those same guidelines also recommend a goal blood pressure < 130/80 mm Hg in patients with diabetes and chronic kidney disease, studies published after the JNC7 guidelines argued against as much. ${ }^{6,35,38,123}$ In addition, guidelines for treatment in the elderly warn about overtreatment, ${ }^{8}$ and the Secondary Prevention of Small Subcortical Strokes (SPS3) study showed no significant differences in recur-

\section{TABLE 5: Secondary causes of elevated blood pressure}

\begin{tabular}{cl}
\hline \multicolumn{1}{c}{ Category } & \multicolumn{1}{c}{ Cause } \\
\hline medications/drugs & oral contraceptives \\
& nonsteroidal antiinflammatory drugs \\
& sympathomimetics \\
& alcohol use \\
& pheochromocytoma \\
& Cushing's syndrome \\
endocrinological & primary aldosteronism \\
& hypothyroidism \\
& hyperparathyroidism \\
& renovascular disease \\
& chronic kidney disease \\
renal disease & OSA \\
& coarctation of the aorta \\
\hline
\end{tabular}


rent stroke rates in patients with lacunar stroke who had been treated to a goal systolic blood pressure $<130 \mathrm{~mm}$ $\mathrm{Hg}$ versus those treated to a rate of $130-149 \mathrm{~mm} \mathrm{Hg} .{ }^{13}$ Thus, guidelines regarding blood pressure targets may change, and we use a more conservative goal of $<140 / 90$ $\mathrm{mm} \mathrm{Hg}$ for most patients with a history of cerebral ischemia. The eighth report of the Joint National Committee guideline is eagerly anticipated in the near future.

\section{Hyperlipidemia}

Risk. Several clinical trials and epidemiological studies have not consistently found dyslipidemia to be a strong risk factor for stroke. ${ }^{45,100,102}$ However, these studies did not separate stroke types (hemorrhagic vs ischemic) or subtypes (lacunar, large vessel, cardioembolic, other), thus diminishing the ability to find an association. ${ }^{3}$

Some studies, including a meta-analysis of solely prospective studies on hypercholesterolemia, have shown an increased risk of stroke with high total cholesterol, high low-density lipoprotein (LDL), high non-high-density lipoprotein (HDL) cholesterol, and low HDL. 21,41,78,104,112 The strongest association between cholesterol and stroke is with the carotid artery subtype of ischemic stroke and lacunar stroke subtypes. ${ }^{50,96,126}$ As regards hypertriglyceridemia, some s2,126 $^{5}$ ut not all ${ }^{63,118}$ prospective epidemiological studies have suggested that hypertriglyceridemia is a moderate risk factor for ischemic stroke.

Diagnosis. A fasting lipid panel is recommended on all patients presenting with ischemic stroke or TIA. In some instances in which triglycerides are elevated, LDL cannot be calculated and the non-HDL cholesterol becomes a surrogate marker.

Treatment. Data from clinical trials in patients with known coronary artery disease have revealed relative risk reductions of first stroke between $20 \%$ and $31 \%$ over $4-5$ years with statin lipid-lowering agents. ${ }^{32,81,134}$ Studies assessing carotid artery disease progression have reported a decrease in progression or actual regression of plaque with the use of statin medications. ${ }^{37,53,68,114,134}$

In patients with hyperlipidemia, LDL lowering by other means (diet, ezetimibe, fibrate) has either no or minimal impact on the primary prevention of stroke..$^{21,36}$ Therefore, it seems plausible that there are additional benefits from statins beyond lipid lowering, including plaque stabilization, reduced inflammation, slowing of carotid arterial disease progression, improved endothelial function, and reduced embolic stroke by preventing myocardial infarction and left ventricular dysfunction. ${ }^{5}$

Only 2 randomized, clinical trials have aimed at secondary prevention in stroke patients alone: a subgroup of the Heart Protection study ${ }^{31}$ and the Stroke Prevention by Aggressive Reduction in Cholesterol Levels (SPARCL) trial. ${ }^{4}$ The latter trial included noncardioembolic ischemic stroke in addition to a minority of intracerebral hemorrhage cases with other vascular risk factors. Patients were randomized to $80 \mathrm{mg}$ of atorvastatin versus placebo. After a median of 4.9 years, there was a $2.2 \%$ absolute risk reduction in recurrent stroke and a $3.5 \%$ reduction in coronary events (HR $0.65,95 \%$ CI $0.49-0.87) .{ }^{4}$
Guidelines for the use of statins in the setting of stroke are slightly complex and controversial. ${ }^{89,117}$ While some believe a statin should be used in all patients with cerebral ischemia regardless of its mechanism, ${ }^{89}$ others (including us) believe that selected use in patients in whom the mechanism is probably atherosclerotic makes more sense. The most recent AHA guidelines ${ }^{54}$ suggest that patients with elevated cholesterol, cerebral ischemia, and comorbid coronary artery disease or equivalent should be treated with a statin, aiming for a goal LDL $<70 \mathrm{mg} / \mathrm{dl}$. In patients without coronary artery disease and evidence of atherosclerosis, statin therapy with a goal LDL $<70 \mathrm{mg} / \mathrm{dl}$ or a $50 \%$ reduction in LDL is recommended. We typically treat large-vessel atherosclerosis, small-vessel disease, and cryptogenic stroke in those over 55 years of age. Patients with a nonatherosclerotic stroke mechanism should be treated according to the National Cholesterol Education Panel (NCEP) III guidelines. ${ }^{48}$ The primary prevention goal in those with a cardiac risk < 20\% over 10 years is $130 \mathrm{mg} / \mathrm{dl}$ (http://cvdrisk.nhlbi.nih.gov).

The risks and benefits of statins must be weighed carefully. Adverse effects can include myopathy, cognitive issues (rarely), liver dysfunction, and the possibility of an increased risk of diabetes at high doses.

Many things remain unknown about the utility of statins in the setting of cerebral ischemia. While the 2 clinical trials mentioned above used a fixed dose of a statin, the guidelines suggest a target LDL goal based mainly on cardiac studies. Thus, it remains unclear if a certain target LDL is more beneficial in stroke patients. Another issue is that many stroke patients are in their 80s and $90 \mathrm{~s}$, whereas the average age in the SPARCL trial was 63 years. The utility and efficacy of statins in the very elderly is not clear. Unlike in cardiac disease, ${ }^{22,116}$ there are no acute statin trials in ischemic stroke or carotid artery disease. Retrospective and observational studies suggest a potential protective benefit in those receiving statins early or those already taking them. ${ }^{24,93}$ Finally, it remains unclear whether targeting HDL or triglycerides has an impact on the secondary prevention of ischemic stroke. ${ }^{16,57}$ Recent cardiac studies ${ }^{16,66}$ have raised doubts on the pharmacological modification of HDL in improving vascular outcomes. However, one study suggested that adding extended-release niacin to statins may reduce carotid intima thickness, ${ }^{124}$ although this was a primary prevention study.

\section{Diabetes}

Risk. Patients with diabetes mellitus have an increased risk of ischemic stroke, recurrence of ischemic stroke/ TIA,${ }^{50}$ and death from ischemic stroke ${ }^{59}$ as compared with those without diabetes mellitus. Diabetic patients have both an increased susceptibility to atherosclerosis and an increased prevalence of atherogenic risk factors, notably hypertension, hyperlipidemia, and obesity. Diabetes mellitus increases the risk of macrovascular and microvascular disease. In patients with diabetes, there is an increased prevalence of atherogenic risk factors, including hypertension, hyperlipidemia, and obesity. Some theorize that dyslipidemia, endothelial dysfunction, and platelet and 
coagulation abnormalities are among the risk factors that promote the development of carotid atherosclerosis in patients with diabetes.

According to case-control and prospective epidemiological studies, the presence of diabetes translates into a 2 - to 6-fold increase in the risk for stroke. ${ }^{59,71}$ Recently, the duration of diabetes was found to be independently associated with ischemic stroke risk. The stroke risk increases 3\% each year after the diagnosis of diabetes and triples with a diabetes duration over 10 years. ${ }^{9}$

Diagnosis. Type 2 diabetes can be diagnosed by assessing fasting glucose, random glucose, or glycated hemoglobin (A1C). A fasting glucose level > $126 \mathrm{mg} / \mathrm{dl}$, a random glucose level $>200 \mathrm{mg} / \mathrm{dl}$ with hyperglycemic symptoms, or an A1C level $\geq 6.5 \%$ indicates a diagnosis of diabetes in an adult.

Treatment. Tight glucose control reduces microvascular complications with neuropathy, retinopathy, and nephropathy. ${ }^{54}$ Clinical trials in patients with established macrovascular disease (cardiovascular, cerebrovascular, or significant vascular risk factors) have not demonstrated a beneficial effect of intensive glucose-lowering therapy or lifestyle modification on macrovascular outcomes in patients with Type 2 diabetes. 6,46,75,97

Given that glucose control does prevent microvascular complications, it makes sense to aim toward a target A1C of approximately $7 \% .^{6}$ A goal of $<8 \%$ may be more appropriate in those with a history of hypoglycemia, advanced macrovascular or microvascular disease, extensive comorbid conditions, and limited life expectancy. ${ }^{6}$ More importantly for macrovascular disease (cardiovascular disease, cerebral vascular disease), however, is to assess and treat other concomitant risk factors such as high blood pressure, hyperlipidemia, obstructive sleep apnea (OSA), and obesity.

\section{Atrial Fibrillation}

Risk. Atrial fibrillation is the most common sustained cardiac arrhythmia in the United States, with a prevalence of approximately $1 \%$ in the general population. ${ }^{131}$ Its prevalence is strongly associated with advancing age, rising to $5 \%$ in people older than 65 years and to about $10 \%$ in those 80 years of age. ${ }^{131}$

The abnormal contraction of the atria resulting in sluggish blood flow may result in thrombus in the left atrial appendage, creating the risk of stroke due to thromboembolism.

The rate of ischemic stroke among patients with nonvalvular atrial fibrillation averages $5 \%$ per year, 2-7 times the rate in people without atrial fibrillation. ${ }^{55}$ Approximately $16 \%$ of all strokes ( 1 of every 6 ) occur in patients with atrial fibrillation. ${ }^{55}$ The risk of stroke increases with age; the annual risk of stroke due to atrial fibrillation is $1.5 \%$ in patients $50-59$ years old, ${ }^{55} 10.3 \%$ in people over 75 years of age, ${ }^{67}$ and $23.5 \%$ in those $80-89$ years. ${ }^{55}$

A number of factors increase the risk of thromboembolism including prior thromboembolic disease. These factors are incorporated into the $\mathrm{CHADS}_{2}$ (Table 6) and $\mathrm{CHA}_{2} \mathrm{DS}_{2}-\mathrm{VASc}$ scores, ${ }^{56,58}$ which aid the clinician in
TABLE 6: The $\mathrm{CHADS}_{2}$ score and thromboembolic risk*

\begin{tabular}{cc}
\hline CHADS $_{2}$ Score & Adjusted Stroke Rate/Yr (range) \\
\hline 0 & $1.9 \%(1.2-3.0)$ \\
1 & $2.8 \%(2.0-3.8)$ \\
2 & $4.0 \%(3.1-5.1)$ \\
3 & $5.9 \%(4.6-7.3)$ \\
4 & $8.5 \%(6.3-11.1)$ \\
5 & $12.5 \%(8.2-17.5)$ \\
6 & $18.2 \%(10.5-27.4)$ \\
\hline
\end{tabular}

* Points for $\mathrm{CHADS}_{2}$ score: 1 point each for congestive heart failure (any history), hypertension, age $\geq 75$ years, diabetes mellitus; and 2 points for prior ischemic stroke or TIA (most experts include a systemic embolic event).

predicting thromboembolic risk in an individual patient. Patients are considered to be at low risk with a score of 0 , at intermediate risk with a score of 1 or 2 , and at high risk with a score $\geq 3$. Note, however, that most experts would consider patients with prior ischemic stroke, TIA, or systemic embolic event to be at high risk even if they had no other risk factors and a score of only 2 .

Diagnosis. The diagnosis of atrial fibrillation is usually made using electrocardiography. Many recent studies have shown that longer-term monitoring in selected patients may increase the likelihood of detecting paroxysmal atrial fibrillation. Thus, patients with an ischemic stroke that appears embolic with no other identified cause and in whom the clinician suspects paroxysmal atrial fibrillation should undergo routine electrocardiography and Holter monitoring, followed by prolonged cardiac monitoring. ${ }^{105,129}$

Treatment. It is clear from many clinical trials that anticoagulation is superior to aspirin alone in preventing strokes from nonvalvular atrial fibrillation, reducing the risk by $68 \% .{ }^{121}$ Anticoagulation is considered in patients with a $\mathrm{CHADS}_{2}$ score of 2 or higher, which includes anyone with cerebral ischemia. Anticoagulation is also superior to the combination of aspirin and clopidogrel..$^{33}$

Anticoagulation using warfarin with a goal international normalized ratio (INR) of $2-3$ is a common option in preventing atrial fibrillation. Recently, other options have included the novel anticoagulants dabigatran, rivaroxaban, and apixaban. When these agents were independently compared with adjusted-dose warfarin (INR 2.0-3.0) in large randomized trials of patients at intermediate to high risk for stroke, equal or better efficacy and safety was demonstrated by these newer anticoagulants compared with warfarin. ${ }^{34,62,98}$ The novel anticoagulants have several advantages over warfarin, including no need for monitoring and less susceptibility to dietary and drug interactions. But there are disadvantages as well: higher cost, twice-daily dosing (dabigatran, apixaban), lack of a reversing agent, impact of chronic kidney disease with dosing and effectiveness, and lack of long-term safety.

Furthermore, only warfarin (never dabigatran, apixaban, and rivaroxaban) should be used for the prevention 


\section{Risk factor management}

of embolization in atrial fibrillation patients with prosthetic heart valves, with mitral stenosis (particularly of rheumatic origin), or with mitral regurgitation or aortic valve disease associated with heart failure that may require valve replacement in the near future.

Emerging alternative options to anticoagulation include the WATCHMAN device, LARIAT procedure, ${ }^{106}$ and other procedures to obliterate or occlude the atrial appendage.

\section{Obstructive Sleep Apnea}

Risk. Obstructive sleep apnea syndrome is a common disorder attributable to recurrent partial or complete collapse of the pharyngeal airway during sleep as a result of functional and/or anatomical factors. ${ }^{40,120}$ The sequelae of OSA are thought to result from a sustained activation of the sympathetic nervous system leading to increased blood pressure and heart rate that, in combination with hemodynamic changes and the release of endothelin, predisposes to the development of coronary artery disease, congestive heart failure, and stroke. ${ }^{120}$ There is a strong association between OSA and atrial fibrillation as well..$^{23}$

Obstructive sleep apnea is an independent risk factor for stroke, causing a 2-fold increase in the risk of first stroke or death. ${ }^{107,139}$ Sleep apnea severity is associated with stroke risk, and patients with severe sleep apnea have 3- to 4-fold increased odds of developing stroke. ${ }^{107,139}$ These findings were independent of obesity and were reproduced in multiple studies..$^{92,107,115,139}$

A recent population study demonstrated that the patients with OSA who had suffered a stroke had higher rates of atrial fibrillation even after accounting for potential confounders. ${ }^{85}$ The most common stroke subtype associated with OSA was atrial fibrillation. ${ }^{85}$

Diagnosis. Screening of stroke patients should be considered, particularly for those with significant hypertension and suspected or actual atrial fibrillation. The STOP BANG questionnaire is an easy screening test (Table 7) but may not be applicable to the patient with a significant breathing-related disorder associated with the stroke itself. $29,30,92,107,115,139$

Overnight pulse oximetry may be helpful as well. While the test can be very specific, its sensitivity ranges from $50 \%$ to $90 \% .{ }^{84}$ The American Academy of Sleep Medicine's practice parameters and the Canadian Sleep
Society's guidelines both recommend overnight in-laboratory polysomnography (PSG) for the diagnosis of OSA, but access to PSG may be limited in certain areas. ${ }^{90,91}$ Homebased or ambulatory monitoring is increasingly becoming available and provides an alternative to in-laboratory PSG, leading to improved access to OSA diagnosis. According to the Canadian Sleep Society's guidelines, portable monitoring studies can be used to confirm the diagnosis of OSA and to institute appropriate treatment in patients with a moderate to high pretest probability of OSA.${ }^{15}$ However, with high clinical suspicion and negative oximetry or ambulatory sleep monitoring results, an in-laboratory PSG would still be needed. The purpose of an overnight PSG is to capture repetitive obstructive apneas/hypopneas during sleep, which typically result in oxygen desaturations, hemodynamic changes, and arousals from sleep. ${ }^{107}$

Treatment. The treatment of OSA with a continuous positive airway pressure (CPAP) device uses positive air pressure as a means of maintaining patency of the airway during sleep. Documented benefits of CPAP therapy in OSA include reduction in systemic blood pressure; improvement in hemodynamic parameters, vascular factors including endothelin, inflammatory markers, and insulin resistance; and attenuation of potentially fatal arrhythmias. ${ }^{40,120}$ Additionally, stroke patients with OSA receiving CPAP therapy may experience improvement in stroke-related impairment in functional and motor domains. ${ }^{18,40,111}$ However, cognitive or sensorimotor impairments may preclude the use of CPAP during the initial stroke recovery period. ${ }^{127}$

\section{Lifestyle Changes}

A number of lifestyle changes have been recommended to reduce future stroke risk. The most recent AHA guidelines pertaining to these risk factors ${ }^{54}$ are listed in Table 8. Further details are reviewed in brief below.

\section{Tobacco Use}

Tobacco use is a significant alterable risk factor contributing to premature morbidity and mortality in the United States, accounting for 443,000 premature deaths from smoking-related illnesses annually. ${ }^{108}$ Smoking has been associated with an increased risk for all stroke subtypes and has a strong dose-response relationship for both

TABLE 7: STOP BANG Questionnaire to screen for OSA*

\begin{tabular}{lll}
\hline Yes & No & Snoring: Do you snore loudly? \\
Yes & No & Tired: Do you often feel tired, fatigued, or sleepy during the daytime? \\
Yes & No & Observed: Has anyone observed you stop breathing during your sleep? \\
Yes & No & Pressure: Do you have or are being treated for high blood pressure \\
Yes & No & Body mass index $>35 ?$ \\
Yes & No & Age older than 50 years? \\
Yes & No & Neck size large? (Do you have a neck that measures more than 16 in $(40 \mathrm{~cm}) ?$ \\
Yes & No & Gender = male? \\
\hline
\end{tabular}

* Results: Score 5-8, high risk; Score 3-4, intermediate risk; Score 0-2, low risk. Reprinted with permission from Chung F et al: High STOP-Bang score indicates a high probability of obstructive sleep apnoea. Br J Anaesth 108:768-775, 2012. 
TABLE 8: Guidelines for lifestyle changes*

\begin{tabular}{ll}
\hline \multicolumn{1}{c}{ Factor } & \multicolumn{1}{c}{ Recommendations } \\
\hline $\begin{array}{l}\text { Smoking } \\
\text { Alcohol }\end{array}$ & $\begin{array}{l}\text { Health care providers should strongly advise every patient w/ stroke or TIA who has smoked in the past yr to quit } \\
\text { Light to moderate levels of alcohol consumption (no more than } 2 \text { drinks per day for men and } 1 \text { drink per day for nonpregnant } \\
\text { women) may be reasonable; nondrinkers should not be counseled to start drinking } \\
\text { Obesity }\end{array}$ \\
$\begin{array}{l}\text { Weight reduction should be considered to achieve goal body mass index } \\
\text { Physical inactivity }\end{array}$ & $\begin{array}{l}\text { For patients w/ ischemic stroke or TIA who are capable of engaging in physical activity, at least 30 mins of moderate-intensity } \\
\text { physical exercise, typically defined as vigorous activity sufficient to break a sweat or noticeably raise heart rate, } 1-3 \text { times a } \\
\text { wk (for example, walking briskly, using an exercise bicycle) may be considered to reduce risk factors \& comorbid conditions } \\
\text { that increase the likelihood of recurrent stroke }\end{array}$ \\
\hline Estrogen use & Discontinue
\end{tabular}

* Recommendations for the factors of smoking, alcohol, and physical inactivity based on those from Furie et al.

ischemic stroke and subarachnoid hemorrhage as well as aneurysm formation. . $^{7,76,80,137}$ Smoking contributes to atherosclerosis and alteration of the coagulation systems (increased fibrinogen, increased platelet aggregation, decreased HDL, and increased hematocrit).

Those who smoke have approximately double the risk of incurring a stroke during their lifetime compared with never smokers. ${ }^{72,125}$ Recent estimates indicate that approximately $19 \%$ of the stroke burden is faulted from current smoking practices. ${ }^{95}$

Studies suggest a $50 \%$ reduction in stroke risk in patients who recently ceased smoking, ${ }^{132}$ and by 5 years after smoking cessation, the risk level can be reduced to that of a never smoker. ${ }^{74,132}$ Therefore, national guidelines recommend smoking cessation for patients with stroke or TIA and suggest the avoidance of environmental tobacco smoke. ${ }^{54}$ Tobacco cessation clinics, quit lines, and nurseled stroke prevention/transitional programs may be useful adjuncts for patients.

\section{Physical Activity}

Regular physical activity has been established as reducing cardiovascular disease. In addition, it appears that physical activity can also decrease stroke in primary prevention studies. ${ }^{44,87}$ A 2010 meta-analysis demonstrated that an increased level of physical activity has the potential to reduce stroke incidence and stroke-related outcomes. ${ }^{44}$

Physical activity is probably beneficial because of its positive effects on blood pressure, weight, diabetes, and cardiovascular disease. There may also be reductions in plasma fibrinogen and platelet activities and triglycerides, as well as an increase in HDL concentration.

While no existing clinical trial has suggested that physical activity decreases recurrent stroke risk, physical activity is beneficial in reducing risk factors contributing to cerebral ischemia. ${ }^{87}$ Current secondary prevention guidelines make the following recommendations: For patients with ischemic stroke or TIA who are capable of engaging in physical activity, at least 30 minutes of moderate-intensity physical exercise 1-3 times a week may be considered to reduce risk factors and comorbid conditions that increase the likelihood of recurrent stroke. ${ }^{54}$ Several studies are assessing the feasibility of cardiac rehabilitation after cerebral ischemia. ${ }^{83}$

\section{Maintaining Normal Weight}

"Overweight" is defined as a body mass index $>25$ $\mathrm{kg} / \mathrm{m}^{2}$; and "obesity," as a body mass index $>30 \mathrm{~kg} / \mathrm{m}^{2}$. Obesity predisposes one to both coronary and cerebrovascular disease. Obesity can also be associated with hypertension, hyperlipidemia, OSA, and elevated glucose. Reducing the risk for recurrent stroke through weight reduction has not been proven, but weight loss is recommended to reduce comorbid conditions. ${ }^{54}$

\section{Nutrition}

A variety of dietary changes can be implemented to lower blood pressure, maintain a healthy weight, and reduce cholesterol. While clinical trial data do not exist on secondary prevention, diets high in grain, fruit, and vegetable intake are recommended. ${ }^{54}$

\section{Alcohol Use}

Several studies have found a "J-shaped" curve relationship between alcohol and stroke risk. One to two drinks per day may protect against cardiovascular disease and stroke, whereas more than 4-5 drinks per day is deleterious.

The AHA recommends no more than two drinks per day for men and one drink per day for women, ${ }^{54}$ where one drink is equal to 12 ounces of beer, 5 ounces of wine, or 1 ounce of hard alcohol.

\section{Hormone Replacement Therapy}

The AHA currently recommends the discontinuation of estrogen in patients with ischemic stroke or TIA. ${ }^{54} \mathrm{We}$ believe, in general, that this strategy is appropriate unless the estrogen is not implicated in the mechanism of stroke. For example, we believe that a patient who has a dissection that heals could return to estrogen-based products as necessary.

\section{Vitamins and Supplementation}

No known supplements are clearly beneficial for patients with cerebral ischemia. Large clinical trials have failed to show stroke reduction through dietary supplementation with the antioxidant vitamins beta-carotene, 


\section{Risk factor management}

\section{TABLE 9: Website references for patients}

\begin{tabular}{|c|c|c|}
\hline General Stroke References & Nutrition & Exercise \\
\hline $\begin{array}{l}\text { American Heart/Stroke Association: } \\
\text { www.americanheart.org } \\
\text { National Stroke Association: } \\
\text { www.stroke.org } \\
\text { Brain Attack Coalition: } \\
\text { www.stroke-site.org } \\
\text { National Aphasia Association: } \\
\text { www.aphasia.org } \\
\text { National Institute of Neurologic Disorders and } \\
\text { Stroke: } \\
\text { www.stroke.nih.gov } \\
\text { Family Caregiver Alliance: } \\
\text { www.caregiver.org } \\
\text { Heart and Stroke Foundation: } \\
\text { www.heartandstroke.com (search term: } \\
\text { stroke) } \\
\text { National Institute of Neurologic Disorders and } \\
\text { Stroke: } \\
\text { www.stroke.nih.gov }\end{array}$ & $\begin{array}{l}\text { American Heart/Stroke Association: } \\
\text { www.americanheart.org (search term: nutri- } \\
\text { tion stroke) } \\
\text { USDA Food and Nutrition Center: } \\
\text { http://fnic.nal.usda.gov } \\
\text { Government Nutrition Information: Choose My } \\
\text { Plate } \\
\text { www.choosemyplate.gov } \\
\text { Academy of Nutrition and Dietetics: } \\
\text { www.eatright.org }\end{array}$ & $\begin{array}{l}\text { American Heart Association: } \\
\text { www.americanheart.org (search term: exercise } \\
\text { after stroke) } \\
\text { National Stroke Association: } \\
\text { www.americanheart.org (search term: exercise) } \\
\text { Government-Supported Fitness Guideline: } \\
\text { www.fitness.gov }\end{array}$ \\
\hline Tobacco & $\begin{array}{l}\text { Stress Management, Behavior Changes After } \\
\text { Stroke, and Suicide Prevention }\end{array}$ & Weight Loss \\
\hline $\begin{array}{l}\text { Become an Ex: } \\
\text { www.becomeanex.org } \\
\text { Nicotine Anonymous: } \\
\text { www.nicotine-anonymous.org } \\
\text { Smokefree: } \\
\text { www.smokefree.gov } \\
\text { Centers for Disease Control: } \\
\text { www.cdc.gov/tobacco } \\
\text { American Lung Association: } \\
\text { www.lungusa.org }\end{array}$ & $\begin{array}{l}\text { American Heart/Stroke Association: } \\
\text { www.americanheart.org (search term: depres- } \\
\text { sion or emotional changes after stroke) } \\
\text { National Stroke Association: } \\
\text { www.stroke.org (search term: depression) } \\
\text { Suicide Prevention: } \\
\text { www.suicidepreventionlifeline.org } \\
\text { 1-800-273-8255 } \\
\text { National Institute of Mental Health: } \\
\text { www.nimh.nih.gov }\end{array}$ & $\begin{array}{l}\text { Healthy Weight: Centers for Disease Control: } \\
\text { www.cdc.gov/healthyweight } \\
\text { Food and Activity Tracker: } \\
\text { www.supertracker.usda.gov }\end{array}$ \\
\hline Diabetes & Blood Pressure & Cholesterol \\
\hline $\begin{array}{l}\text { American Diabetes Association: } \\
\text { www.diabetes.org } \\
\text { American Heart/Stroke Association: } \\
\text { www.americanheart.org (search term: } \\
\quad \text { diabetes) }\end{array}$ & $\begin{array}{l}\text { American Heart/Stroke Association: } \\
\text { www.americanheart.org (search term: blood } \\
\text { pressure) } \\
\text { National Stroke Association: } \\
\text { www.stroke.org (search term: blood pressure) }\end{array}$ & $\begin{array}{l}\text { American Heart/Stroke Association: } \\
\text { www.americanheart.org (search term: choles- } \\
\text { terol) } \\
\text { National Stroke Association: } \\
\text { www.stroke.org (search term: cholesterol) }\end{array}$ \\
\hline Alcohol & Communication Tips/Aphasia & Atrial Fibrillation \\
\hline \multirow[t]{2}{*}{$\begin{array}{l}\text { Alcoholics Anonymous: } \\
\text { www.aa.org }\end{array}$} & $\begin{array}{l}\text { National Aphasia Association: } \\
\text { www.aphasia.org } \\
\text { American Heart Association: } \\
\text { www.americanheart.org (search term: com- } \\
\text { munication after stroke) }\end{array}$ & $\begin{array}{l}\text { American Heart/Stroke Association: } \\
\text { www.americanheart.org (search term: atrial } \\
\text { fibrillation) } \\
\text { National Stroke Association: } \\
\text { www.stroke.org (search term: atrial fibrillation) } \\
\text { Heart and Stroke Foundation: } \\
\text { www.heartandstroke.com (search term: atrial } \\
\text { fibrillation) }\end{array}$ \\
\hline & Dietary Supplements & Reading Materials \\
\hline $\begin{array}{l}\text { National Sleep Foundation: } \\
\text { www.sleepfoundation.org } \\
\text { Better Sleep Council: } \\
\text { www.bettersleep.org }\end{array}$ & $\begin{array}{l}\text { National Institutes of Health Information on } \\
\text { Nutritional Supplements: } \\
\text { www.dietary-supplements.info.nih.gov }\end{array}$ & $\begin{array}{l}\text { American Heart Association: } \\
\text { magazine: Stroke Connection } \\
\text { book: Life After Stroke: The Guide to Recover- } \\
\text { ing Your Health and Preventing Another } \\
\text { Stroke } \\
\text { www.americanheart.org }\end{array}$ \\
\hline
\end{tabular}


vitamin C, and vitamin E. ${ }^{64}$ In populations with vitaminfortified foods, there is no reliable evidence that supplementation with folic acid and vitamin B12 prevents stroke. ${ }^{64}$ While not specifically assessed in stroke patients, accumulating evidence leads one to question whether fish oil supplementation reduces vascular events in the secondary prevention of coronary artery disease. ${ }^{77,109} \mathrm{Re}$ cently, calcium supplements have been shown to potentially increase the risk of vascular disease. ${ }^{17,138}$ In patients with cerebral ischemia, the risk/benefit ratio should be assessed until further data are available.

\section{Practical Issues in Stroke Prevention}

Despite existing knowledge, there is a lack of systematic assessment, and secondary stroke prevention strategies are underutilized, resulting in a gap between existing evidence and actual practice. ${ }^{69,73}$ Several strategies to address the problems that exist in the evidence-practice gap must tackle each of the categories of patient factors, physician factors, and health care factors. These strategies must address the education of patients, the systematic identification and early treatment of risk factors, and the long-term follow-up and surveillance of patients.

A nurse or other member of the neurosurgical team can perform a systematic review of risk factors to ensure that none are missed. Education on individual risk factors can be provided to patients and their families. Many websites with reliable information on individual risk factors are available (Table 9). Setting realistic targets and assisting patients in reaching their goals can be useful. In addition to websites and written brochures, there are many self-help smartphone applications that allow patients to track their weight, blood pressure, and other health measurements. Assisting patients in consultations or followups appropriate for their risk factors is also key to their success. While a neurosurgeon may not be the appropriate person to follow up on the lipids and the safety labs for statins, ensuring appropriate follow-up is very important. Stroke prevention and transitional programs can also be incorporated into the practice to ensure ongoing commitment and education toward goals. ${ }^{51}$

\section{Conclusions}

Identification and treatment of modifiable stroke risk factors can significantly reduce ischemic stroke and myocardial infarction as well as prevent long-term morbidity and mortality after first stroke or TIA. Neurosurgeons should be aware of the specific risk factors and general recommendations for stroke patients. A select member of the neurosurgical team may be useful in aiding the neurosurgeon to assess risk factors and assist patients for longterm success.

\section{Disclosure}

The authors report no conflict of interest concerning the materials or methods used in this study or the findings specified in this paper.

Author contributions to the study and manuscript prepara- tion include the following. Conception and design: both authors. Acquisition of data: both authors. Drafting the article: both authors. Reviewed submitted version of manuscript: both authors.

\section{References}

1. Aiyagari V, Gorelick PB: Management of blood pressure for acute and recurrent stroke. Stroke 40:2251-2256, 2009

2. ALLHAT Officers and Coordinators for the ALLHAT Collaborative Research Group: Major outcomes in high-risk hypertensive patients randomized to angiotensin-converting enzyme inhibitor or calcium channel blocker vs diuretic: the Antihypertensive and Lipid-Lowering Treatment to Prevent Heart Attack Trial (ALLHAT). JAMA 288:2981-2997, 2002 (Errata in JAMA 289:178, 2003 and JAMA 291:2196, 2004)

3. Amarenco P: Lipid lowering and recurrent stroke: another stroke paradox? Eur Heart J 26:1818-1819, 2005

4. Amarenco P, Bogousslavsky J, Callahan A III, Goldstein LB, Hennerici M, Rudolph AE, et al: High-dose atorvastatin after stroke or transient ischemic attack. N Engl J Med 355:549_ 559,2006

5. Amarenco P, Labreuche J, Lavallée P, Touboul PJ: Statins in stroke prevention and carotid atherosclerosis: systematic review and up-to-date meta-analysis. Stroke 35:2902-2909, 2004

6. American Diabetes Association: Standards of medical care in diabetes-2013. Diabetes Care 36 (Suppl 1):S11-S66, 2013

7. Antiplatelet Trialists' Collaboration: Collaborative overview of randomised trials of antiplatelet therapy. Prevention of death, myocardial infarction, and stroke by prolonged antiplatelet therapy in various categories of patients. BMJ 308: 81-106, 1994 (Erratum in BMJ 308:1540, 1994)

8. Aronow WS, Fleg JL, Pepine CJ, Artinian NT, Bakris G, Brown AS, et al: ACCF/AHA 2011 expert consensus document on hypertension in the elderly: a report of the American College of Cardiology Foundation Task Force on Clinical Expert Consensus Documents. Circulation 123:2434-2506, 2011

9. Banerjee C, Moon YP, Paik MC, Rundek T, Mora-McLaughlin C, Vieira JR, et al: Duration of diabetes and risk of ischemic stroke: the Northern Manhattan Study. Stroke 43:1212-1217, 2012

10. Bangalore S, Parkar S, Grossman E, Messerli FH: A metaanalysis of 94,492 patients with hypertension treated with beta blockers to determine the risk of new-onset diabetes mellitus. Am J Cardiol 100:1254-1262, 2007

11. Bangalore S, Wild D, Parkar S, Kukin M, Messerli FH: Betablockers for primary prevention of heart failure in patients with hypertension insights from a meta-analysis. J Am Coll Cardiol 52:1062-1072, 2008

12. Benavente OR, Hart RG, McClure LA, Szychowski JM, Coffey CS, Pearce LA: Effects of clopidogrel added to aspirin in patients with recent lacunar stroke. N Engl J Med 367:817825,2012

13. Benavente OR, White CL, Pearce L, Pergola P, Roldan A, Benavente MF, et al: The Secondary Prevention of Small Subcortical Strokes (SPS3) study. Int J Stroke 6:164-175, 2011

14. Bhatt DL, Fox KA, Hacke W, Berger PB, Black HR, Boden WE, et al: Clopidogrel and aspirin versus aspirin alone for the prevention of atherothrombotic events. N Engl J Med 354: 1706-1717, 2006

15. Blackman A, McGregor C, Dales R, Driver HS, Dumov I, Fleming J, et al: Canadian Sleep Society/Canadian Thoracic Society position paper on the use of portable monitoring for the diagnosis of obstructive sleep apnea/hypopnea in adults. Can Respir J 17:229-232, 2010

16. Boden WE, Probstfield JL, Anderson T, Chaitman BR, Desvignes-Nickens $\mathrm{P}$, Koprowicz K, et al: Niacin in patients with low HDL cholesterol levels receiving intensive statin therapy. N Engl J Med 365:2255-2267, 2011 
17. Bolland MJ, Grey A, Avenell A, Gamble GD, Reid IR: Calcium supplements with or without vitamin D and risk of cardiovascular events: reanalysis of the Women's Health Initiative limited access dataset and meta-analysis. BMJ 342:d2040, 2011

18. Bravata DM, Concato J, Fried T, Ranjbar N, Sadarangani $\mathrm{T}$, McClain V, et al: Continuous positive airway pressure: evaluation of a novel therapy for patients with acute ischemic stroke. Sleep 34:1271-1277, 2011

19. Bronner LL, Kanter DS, Manson JE: Primary prevention of stroke. N Engl J Med 333:1392-1400, 1995

20. Brook RD, Appel LJ, Rubenfire M, Ogedegbe G, Bisognano JD, Elliott WJ, et al: Beyond medications and diet: alternative approaches to lowering blood pressure: a scientific statement from the American Heart Association. Hypertension 61:1360-1383, 2013

21. Bucher HC, Griffith LE, Guyatt GH: Effect of HMGcoA reductase inhibitors on stroke. A meta-analysis of randomized, controlled trials. Ann Intern Med 128:89-95, 1998

22. Cannon CP, Braunwald E, McCabe CH, Rader DJ, Rouleau JL, Belder R, et al: Intensive versus moderate lipid lowering with statins after acute coronary syndromes. N Engl J Med 350:1495-1504, 2004

23. Caples SM, Somers VK: Sleep-disordered breathing and atrial fibrillation. Prog Cardiovasc Dis 51:411-415, 2009

24. Cappellari M, Bovi P, Moretto G, Zini A, Nencini P, Sessa M, et al: The THRombolysis and STatins (THRaST) study. Neurology 80:655-661, 2013

25. CAPRIE Steering Committee: A randomised, blinded, trial of clopidogrel versus aspirin in patients at risk of ischaemic events (CAPRIE). Lancet 348:1329-1339, 1996

26. Chimowitz MI, Lynn MJ, Derdeyn CP, Turan TN, Fiorella D, Lane BF, et al: Stenting versus aggressive medical therapy for intracranial arterial stenosis. N Engl J Med 365:993-1003, 2011

27. Chimowitz MI, Lynn MJ, Howlett-Smith H, Stern BJ, Hertzberg VS, Frankel MR, et al: Comparison of warfarin and aspirin for symptomatic intracranial arterial stenosis. N Engl J Med 352:1305-1316, 2005

28. Chobanian AV, Bakris GL, Black HR, Cushman WC, Green LA, Izzo JL Jr, et al: Seventh report of the Joint National Committee on Prevention, Detection, Evaluation, and Treatment of High Blood Pressure. Hypertension 42:1206-1252, 2003

29. Chung F, Subramanyam R, Liao P, Sasaki E, Shapiro C, Sun Y: High STOP-Bang score indicates a high probability of obstructive sleep apnoea. Br J Anaesth 108:768-775, 2012

30. Chung F, Yegneswaran B, Liao P, Chung SA, Vairavanathan S, Islam S, et al: STOP questionnaire: a tool to screen patients for obstructive sleep apnea. Anesthesiology 108:812-821, 2008

31. Collins R, Armitage J, Parish S, Sleigh P, Peto R: MRC/BHF Heart Protection Study of cholesterol-lowering with simvastatin in 5963 people with diabetes: a randomised placebocontrolled trial. Lancet 361:2005-2016, 2003

32. Collins R, Armitage J, Parish S, Sleight P, Peto R: Effects of cholesterol-lowering with simvastatin on stroke and other major vascular events in 20536 people with cerebrovascular disease or other high-risk conditions. Lancet 363:757-767, 2004

33. Connolly S, Pogue J, Hart R, Pfeffer M, Hohnloser S, Chrolavicius S, et al: Clopidogrel plus aspirin versus oral anticoagulation for atrial fibrillation in the Atrial fibrillation Clopidogrel Trial with Irbesartan for prevention of Vascular Events (ACTIVE W): a randomised controlled trial. Lancet 367:1903-1912, 2006

34. Connolly SJ, Ezekowitz MD, Yusuf S, Eikelboom J, Oldgren J, Parekh A, et al: Dabigatran versus warfarin in patients with atrial fibrillation. N Engl J Med 361:1139-1151, 2009

35. Cooper-DeHoff RM, Gong Y, Handberg EM, Bavry AA, Denardo SJ, Bakris GL, et al: Tight blood pressure control and cardiovascular outcomes among hypertensive patients with diabetes and coronary artery disease. JAMA 304:61-68, 2010
36. Corvol JC, Bouzamondo A, Sirol M, Hulot JS, Sanchez P, Lechat P: Differential effects of lipid-lowering therapies on stroke prevention: a meta-analysis of randomized trials. Arch Intern Med 163:669-676, 2003

37. Crouse JR III, Craven TE, Hagaman AP, Bond MG: Association of coronary disease with segment-specific intimal-medial thickening of the extracranial carotid artery. Circulation 92: 1141-1147, 1995

38. Cushman WC, Evans GW, Byington RP, Goff DC Jr, Grimm $\mathrm{RH}$ Jr, Cutler JA, et al: Effects of intensive blood-pressure control in type 2 diabetes mellitus. N Engl J Med 362:15751585,2010

39. Dahlöf B, Lindholm LH, Hansson L, Scherstén B, Ekbom T, Wester PO: Morbidity and mortality in the Swedish Trial in Old Patients with Hypertension (STOP-Hypertension). Lancet 338:1281-1285, 1991

40. Davis AP, Billings ME, Longstreth WT Jr, Khot SP: Early diagnosis and treatment of obstructive sleep apnea after stroke: are we neglecting a modifiable stroke risk factor? Neurology Clin Pract 3:192-201, 2013

41. Di Angelantonio E, Sarwar N, Perry P, Kaptoge S, Ray KK, Thompson A, et al: Major lipids, apolipoproteins, and risk of vascular disease. JAMA 302:1993-2000, 2009

42. Diener HC, Bogousslavsky J, Brass LM, Cimminiello C, Csiba L, Kaste M, et al: Aspirin and clopidogrel compared with clopidogrel alone after recent ischaemic stroke or transient ischaemic attack in high-risk patients (MATCH): randomised, double-blind, placebo-controlled trial. Lancet 364:331-337, 2004

43. Diener HC, Cunha L, Forbes C, Sivenius J, Smets P, Lowenthal A: European Stroke Prevention Study 2. Dipyridamole and acetylsalicylic acid in the secondary prevention of stroke. J Neurol Sci 143:1-13, 1996

44. Diep L, Kwagyan J, Kurantsin-Mills J, Weir R, Jayam-Trouth A: Association of physical activity level and stroke outcomes in men and women: a meta-analysis. J Womens Health (Larchmt) 19:1815-1822, 2010

45. Donnan GA, Davis SM: Stroke and cholesterol: weakness of risk versus strength of therapy. Stroke 35:1526, 2004

46. Duckworth W, Abraira C, Moritz T, Reda D, Emanuele N, Reaven PD, et al: Glucose control and vascular complications in veterans with type 2 diabetes. N Engl J Med 360:129-139, 2009

47. ESPRIT Group: Medium intensity oral anticoagulants versus aspirin after cerebral ischaemia of arterial origin (ESPRIT): a randomised controlled trial. Lancet Neurol 6:115-124, 2007

48. Expert Panel on Detection, Evaluation, and Treatment of High Blood Cholesterol in Adults: Executive summary of the third report of the National Cholesterol Education Program (NCEP) Expert Panel on detection, evaluation, and treatment of high blood cholesterol in adults (Adult Treatment Panel III). JAMA 285:2486-2497, 2001

49. Feinberg WM: Primary and secondary stroke prevention. Curr Opin Neurol 9:46-52, 1996

50. Fine-Edelstein JS, Wolf PA, O'Leary DH, Poehlman H, Belanger AJ, Kase CS, et al: Precursors of extracranial carotid atherosclerosis in the Framingham Study. Neurology 44: 1046-1050, 1994

51. Flemming KD, Allison TG, Covalt JL, Herzig DE, Brown RD: Utility of a post-hospitalization stroke prevention program managed by nurses. Hosp Pract (1995) 41:70-79, 2013

52. Freiberg JJ, Tybjaerg-Hansen A, Jensen JS, Nordestgaard BG: Nonfasting triglycerides and risk of ischemic stroke in the general population. JAMA 300:2142-2152, 2008

53. Furberg CD, Adams HP Jr, Applegate WB, Byington RP, Espeland MA, Hartwell T, et al: Effect of lovastatin on early carotid atherosclerosis and cardiovascular events. Circulation 90:1679-1687, 1994

54. Furie KL, Kasner SE, Adams RJ, Albers GW, Bush RL, Fagan SC, et al: Guidelines for the prevention of stroke in pa- 
tients with stroke or transient ischemic attack: a guideline for healthcare professionals from the American Heart Association/American Stroke Association. Stroke 42:227-276, 2011

55. Fuster V, Rydén LE, Cannom DS, Crijns HJ, Curtis AB, Ellenbogen KA, et al: 2011 ACCF/AHA/HRS focused updates incorporated into the ACC/AHA/ESC 2006 guidelines for the management of patients with atrial fibrillation: a report of the American College of Cardiology Foundation/American Heart Association Task Force on practice guidelines. Circulation 123:e269-e367, 2011

56. Gage BF, Waterman AD, Shannon W, Boechler M, Rich MW, Radford MJ: Validation of clinical classification schemes for predicting stroke: results from the National Registry of Atrial Fibrillation. JAMA 285:2864-2870, 2001

57. Ginsberg HN, Elam MB, Lovato LC, Crouse JR III, Leiter LA, Linz P, et al: Effects of combination lipid therapy in type 2 diabetes mellitus. N Engl J Med 362:1563-1574, 2010

58. Go AS, Hylek EM, Chang Y, Phillips KA, Henault LE, Capra $\mathrm{AM}$, et al: Anticoagulation therapy for stroke prevention in atrial fibrillation: how well do randomized trials translate into clinical practice? JAMA 290:2685-2692, 2003

59. Goldstein LB, Adams R, Alberts MJ, Appel LJ, Brass LM, Bushnell CD, et al: Primary prevention of ischemic stroke: a guideline from the American Heart Association/American Stroke Association Stroke Council: cosponsored by the Atherosclerotic Peripheral Vascular Disease Interdisciplinary Working Group; Cardiovascular Nursing Council; Clinical Cardiology Council; Nutrition, Physical Activity, and Metabolism Council; and the Quality of Care and Outcomes Research Interdisciplinary Working Group. Stroke 37:1583-1633, 2006

60. Gorelick PB, Sacco RL, Smith DB, Alberts M, Mustone-Alexander L, Rader D, et al: Prevention of a first stroke: a review of guidelines and a multidisciplinary consensus statement from the National Stroke Association. JAMA 281:1112-1120, 1999

61. Gorelick PB, White WB: $\beta$-Blockers in neurologic practice: should we be advising caution? Neurology 77:708-709, 2011

62. Granger CB, Alexander JH, McMurray JJ, Lopes RD, Hylek EM, Hanna M, et al: Apixaban versus warfarin in patients with atrial fibrillation. N Engl J Med 365:981-992, 2011

63. Håheim LL, Holme I, Hjermann I, Leren P: Risk factors of stroke incidence and mortality. A 12-year follow-up of the Oslo Study. Stroke 24:1484-1489, 1993

64. Hankey GJ: Vitamin supplementation and stroke prevention. Stroke 43:2814-2818, 2012

65. Hankey GJ, Warlow CP: Treatment and secondary prevention of stroke: evidence, costs, and effects on individuals and populations. Lancet 354:1457-1463, 1999

66. Harrison SC, Holmes MV, Humphries SE: Mendelian randomisation, lipids, and cardiovascular disease. Lancet 380:543-545, 2012

67. Hobbs FD, Fitzmaurice DA, Mant J, Murray E, Jowett S, Bryan S, et al: A randomised controlled trial and cost-effectiveness study of systematic screening (targeted and total population screening) versus routine practice for the detection of atrial fibrillation in people aged 65 and over. The SAFE study. Health Technol Assess 9:iii-iv, ix-x, 1-74, 2005

68. Hodis HN: Reversibility of atherosclerosis - evolving perspectives from two arterial imaging clinical trials: the cholesterol lowering atherosclerosis regression study and the monitored atherosclerosis regression study. J Cardiovasc Pharmacol 25 (Suppl 4):S25-S31, 1995

69. Holloway RG, Benesch C, Rush SR: Stroke prevention: narrowing the evidence-practice gap. Neurology 54:1899-1906, 2000

70. Jamerson K, Weber MA, Bakris GL, Dahlöf B, Pitt B, Shi V, et al: Benazepril plus amlodipine or hydrochlorothiazide for hypertension in high-risk patients. N Engl J Med 359:2417-2428, 2008
71. Janghorbani M, Hu FB, Willett WC, Li TY, Manson JE, Logroscino G, et al: Prospective study of type 1 and type 2 diabetes and risk of stroke subtypes: the Nurses' Health Study. Diabetes Care 30:1730-1735, 2007

72. Jha P, Ramasundarahettige C, Landsman V, Rostron B, Thun $\mathrm{M}$, Anderson RN, et al: 21st-century hazards of smoking and benefits of cessation in the United States. N Engl J Med 368: 341-350, 2013

73. Kalra L, Perez I, Melbourn A: Stroke risk management: changes in mainstream practice. Stroke 29:53-57, 1998

74. Kawachi I, Colditz GA, Stampfer MJ, Willett WC, Manson JE, Rosner B, et al: Smoking cessation and decreased risk of stroke in women. JAMA 269:232-236, 1993

75. King P, Peacock I, Donnelly R: The UK prospective diabetes study (UKPDS): clinical and therapeutic implications for type 2 diabetes. Br J Clin Pharmacol 48:643-648, 1999

76. Kurth T, Kase CS, Berger K, Gaziano JM, Cook NR, Buring JE: Smoking and risk of hemorrhagic stroke in women. Stroke 34:2792-2795, 2003

77. Kwak SM, Myung SK, Lee YJ, Seo HG: Efficacy of omega-3 fatty acid supplements (eicosapentaenoic acid and docosahexaenoic acid) in the secondary prevention of cardiovascular disease: a meta-analysis of randomized, double-blind, placebo-controlled trials. Arch Intern Med 172:686-694, 2012

78. Law MR, Wald NJ, Rudnicka AR: Quantifying effect of statins on low density lipoprotein cholesterol, ischaemic heart disease, and stroke: systematic review and meta-analysis. BMJ 326:1423, 2003

79. Lewington S, Clarke R, Qizilbash N, Peto R, Collins R: Agespecific relevance of usual blood pressure to vascular mortality: a meta-analysis of individual data for one million adults in 61 prospective studies. Lancet 360:1903-1913, 2002

80. Li C, Engström G, Hedblad B, Berglund G, Janzon L: Risk factors for stroke in subjects with normal blood pressure: a prospective cohort study. Stroke 36:234-238, 2005

81. Long-Term Intervention with Pravastatin in Ischaemic Disease (LIPID) Study Group: Prevention of cardiovascular events and death with pravastatin in patients with coronary heart disease and a broad range of initial cholesterol levels. $\mathbf{N}$ Engl J Med 339:1349-1357, 1998

82. Lonn E, Yusuf S, Dzavik V, Doris C, Yi Q, Smith S, et al: Effects of ramipril and vitamin $\mathrm{E}$ on atherosclerosis: the study to evaluate carotid ultrasound changes in patients treated with ramipril and vitamin E (SECURE). Circulation 103:919-925, 2001

83. Mackay-Lyons M, Thornton M, Ruggles T, Che M: Non-pharmacological interventions for preventing secondary vascular events after stroke or transient ischemic attack. Cochrane Database Syst Rev 3:CD008656, 2013

84. Malhotra A, White DP: Obstructive sleep apnoea. Lancet 360:237-245, 2002

85. Mansukhani MP, Calvin AD, Kolla BP, Brown RD Jr, Lipford MC, Somers VK, et al: The association between atrial fibrillation and stroke in patients with obstructive sleep apnea: a population-based case-control study. Sleep Med 14:243-246, 2013

86. Markus HS, Droste DW, Kaps M, Larrue V, Lees KR, Siebler M, et al: Dual antiplatelet therapy with clopidogrel and aspirin in symptomatic carotid stenosis evaluated using doppler embolic signal detection: the Clopidogrel and Aspirin for Reduction of Emboli in Symptomatic Carotid Stenosis (CARESS) trial. Circulation 111:2233-2240, 2005

87. McDonnell MN, Hillier SL, Hooker SP, Le A, Judd SE, Howard VJ: Physical activity frequency and risk of incident stroke in a national US study of blacks and whites. Stroke 44:25192524,2013

88. Mohr JP, Thompson JL, Lazar RM, Levin B, Sacco RL, Furie $\mathrm{KL}$, et al: A comparison of warfarin and aspirin for the prevention of recurrent ischemic stroke. N Engl J Med 345: 1444-1451, 2001 
89. Moonis M: High-dose statins should be used in all acute ischemic strokes. Stroke 43:1992-1993, 2012

90. Morgenthaler TI, Kapen S, Lee-Chiong T, Alessi C, Boehlecke B, Brown T, et al: Practice parameters for the medical therapy of obstructive sleep apnea. Sleep 29:1031-1035, 2006

91. Morgenthaler TI, Olson EJ, Gay P, Decker PA, Herold D, Moore W, et al: Effect of a targeted obstructive sleep apnea consult to improve access and quality at a sleep disorders center. J Clin Sleep Med 2:49-56, 2006

92. Nachtmann A, Stang A, Wang YM, Wondzinski E, Thilmann AF: Association of obstructive sleep apnea and stenotic artery disease in ischemic stroke patients. Atherosclerosis 169: 301-307, 2003

93. Ní Chróinín D, Asplund K, Åsberg S, Callaly E, CuadradoGodia E, Díez-Tejedor E, et al: Statin therapy and outcome after ischemic stroke: systematic review and meta-analysis of observational studies and randomized trials. Stroke 44: 448-456, 2013

94. Ntaios G, Bath P, Michel P: Blood pressure treatment in acute ischemic stroke: a review of studies and recommendations. Curr Opin Neurol 23:46-52, 2010

95. O'Donnell MJ, Xavier D, Liu L, Zhang H, Chin SL, RaoMelacini $\mathrm{P}$, et al: Risk factors for ischaemic and intracerebral haemorrhagic stroke in 22 countries (the INTERSTROKE study): a case-control study. Lancet 376:112-123, 2010

96. O'Leary DH, Polak JF, Kronmal RA, Kittner SJ, Bond MG, Wolfson SK Jr, et al: Distribution and correlates of sonographically detected carotid artery disease in the Cardiovascular Health Study. Stroke 23:1752-1760, 1992

97. Patel A, MacMahon S, Chalmers J, Neal B, Billot L, Woodward $\mathrm{M}$, et al: Intensive blood glucose control and vascular outcomes in patients with type 2 diabetes. N Engl J Med 358: 2560-2572, 2008

98. Patel MR, Mahaffey KW, Garg J, Pan G, Singer DE, Hacke W, et al: Rivaroxaban versus warfarin in nonvalvular atrial fibrillation. N Engl J Med 365:883-891, 2011

99. Perry HM Jr, Davis BR, Price TR, Applegate WB, Fields WS, Guralnik JM, et al: Effect of treating isolated systolic hypertension on the risk of developing various types and subtypes of stroke: the Systolic Hypertension in the Elderly Program (SHEP). JAMA 284:465-471, 2000

100. Piechowski-Jozwiak B, Bogousslavsky J: Stroke prevention with lipid-lowering therapy. Expert Rev Neurother 4: 233-239, 2004

101. PROGRESS Collaborative Group: Randomised trial of a perindopril-based blood-pressure-lowering regimen among 6,105 individuals with previous stroke or transient ischaemic attack. Lancet 358:1033-1041, 2001 (Errata in Lancet 358: 1556, 2001 and Lancet 359:2120, 2002)

102. Prospective Studies Collaboration: Cholesterol, diastolic blood pressure, and stroke: 13,000 strokes in 450,000 people in 45 prospective cohorts. Prospective studies collaboration. Lancet 346: 1647-1653, 1995

103. Pullicino PM, Thompson JL, Sacco RL, Sanford AR, Qian M, Teerlink JR, et al: Stroke in heart failure in sinus rhythm: the Warfarin versus Aspirin in Reduced Cardiac Ejection Fraction trial. Cerebrovasc Dis 36:74-78, 2013

104. Qizilbash N, Jones L, Warlow C, Mann J: Fibrinogen and lipid concentrations as risk factors for transient ischaemic attacks and minor ischaemic strokes. BMJ 303:605-609, 1991

105. Rabinstein AA, Fugate JE, Mandrekar J, Burns JD, Seet RC, Dupont SA, et al: Paroxysmal atrial fibrillation in cryptogenic stroke: a case-control study. J Stroke Cerebrovasc Dis [epub ahead of print], 2013

106. Reddy VY, Doshi SK, Sievert H, Buchbinder M, Neuzil P, Huber K, et al: Percutaneous left atrial appendage closure for stroke prophylaxis in patients with atrial fibrillation: 2.3year follow-up of the PROTECT AF (Watchman Left Atrial Appendage System for Embolic Protection in Patients with Atrial Fibrillation) Trial. Circulation 127:720-729, 2013
107. Redline S, Yenokyan G, Gottlieb DJ, Shahar E, O'Connor GT, Resnick HE, et al: Obstructive sleep apnea-hypopnea and incident stroke: the sleep heart health study. Am J Respir Crit Care Med 182:269-277, 2010

108. Roger VL, Go AS, Lloyd-Jones DM, Benjamin EJ, Berry JD, Borden WB, et al: Heart disease and stroke statistics-2012 update: a report from the American Heart Association. Circulation 125:e2-e220, 2012 (Erratm in Circulation 125: e1002, 2012)

109. Roncaglioni MC, Tombesi M, Avanzini F, Barlera S, Caimi V, Longoni $\mathrm{P}$, et al: $\mathrm{n}-3$ fatty acids in patients with multiple cardiovascular risk factors. N Engl J Med 368:1800-1808, 2013

110. Rothwell PM: Limitations of the usual blood-pressure hypothesis and importance of variability, instability, and episodic hypertension. Lancet 375:938-948, 2010

111. Ryan CM, Bayley M, Green R, Murray BJ, Bradley TD: Influence of continuous positive airway pressure on outcomes of rehabilitation in stroke patients with obstructive sleep apnea. Stroke 42:1062-1067, 2011

112. Sacco RL, Benson RT, Kargman DE, Boden-Albala B, Tuck C, Lin IF, et al: High-density lipoprotein cholesterol and ischemic stroke in the elderly: the Northern Manhattan Stroke Study. JAMA 285:2729-2735, 2001

113. Sacco RL, Diener HC, Yusuf S, Cotton D, Ounpuu S, Lawton WA, et al: Aspirin and extended-release dipyridamole versus clopidogrel for recurrent stroke. N Engl J Med 359: 1238-1251, 2008

114. Salonen R, Nyyssönen K, Porkkala E, Rummukainen J, Belder R, Park JS, et al: Kuopio Atherosclerosis Prevention Study (KAPS). A population-based primary preventive trial of the effect of LDL lowering on atherosclerotic progression in carotid and femoral arteries. Circulation 92:1758-1764, 1995

115. Schulz R, Olschewski H, GrimmingerF, Seeger W: [Prevalence of stroke and transitory ischemic attacks in obstructive sleep apnea: a retrospective analysis of 187 consecutive patients.] Pneumologie 54:575-579, 2000 (Ger)

116. Schwartz GG, Olsson AG, Ezekowitz MD, Ganz P, Oliver MF, Waters D, et al: Effects of atorvastatin on early recurrent ischemic events in acute coronary syndromes: the MIRACL study: a randomized controlled trial. JAMA 285:1711-1718, 2001

117. Selim MH, Molina CA: High-dose statin for every stroke: the good, the bad, and the unknown. Stroke 43:1996-1997, 2012

118. Shahar E, Chambless LE, Rosamond WD, Boland LL, Ballantyne CM, McGovern PG, et al: Plasma lipid profile and incident ischemic stroke: the Atherosclerosis Risk in Communities (ARIC) study. Stroke 34:623-631, 2003

119. Shinohara Y, Katayama Y, Uchiyama S, Yamaguchi T, Handa S, Matsuoka K, et al: Cilostazol for prevention of secondary stroke (CSPS 2): an aspirin-controlled, double-blind, randomised non-inferiority trial. Lancet Neurol 9:959-968, 2010

120. Somers VK, White DP, Amin R, Abraham WT, Costa F, Culebras A, et al: Sleep apnea and cardiovascular disease: an American Heart Association/American College Of Cardiology Foundation Scientific Statement from the American Heart Association Council for High Blood Pressure Research Professional Education Committee, Council on Clinical Cardiology, Stroke Council, and Council On Cardiovascular Nursing. Circulation 118:1080-1111, 2008

121. Stroke Prevention in Atrial Fibrillation II Study Investigators: Warfarin versus aspirin for prevention of thromboembolism in atrial fibrillation: Stroke Prevention in Atrial Fibrillation II Study. Lancet 343:687-691, 1994

122. Stroke Prevention in Reversible Ischemia Trial (SPIRIT) Study Group: A randomized trial of anticoagulants versus aspirin after cerebral ischemia of presumed arterial origin. Ann Neurol 42:857-865, 1997 


\section{B. S. Katz and K. D. Flemming}

123. Taler SJ, Agarwal R, Bakris GL, Flynn JT, Nilsson PM, Rahman M, et al: KDOQI US commentary on the 2012 KDIGO clinical practice guideline for management of blood pressure in CKD. Am J Kidney Dis 62:201-213, 2013

124. Taylor AJ, Villines TC, Stanek EJ, Devine PJ, Griffen L, Miller M, et al: Extended-release niacin or ezetimibe and carotid intima-media thickness. N Engl J Med 361:21132122,2009

125. Thun MJ, Carter BD, Feskanich D, Freedman ND, Prentice $\mathrm{R}$, Lopez AD, et al: 50-year trends in smoking-related mortality in the United States. N Engl J Med 368:351-364, 2013

126. Tirschwell DL, Smith NL, Heckbert SR, Lemaitre RN, Longstreth WT Jr, Psaty BM: Association of cholesterol with stroke risk varies in stroke subtypes and patient subgroups. Neurology 63:1868-1875, 2004

127. Tomfohr LM, Hemmen T, Natarajan L, Ancoli-Israel S, Loredo JS, Heaton RK, et al: Continuous positive airway pressure for treatment of obstructive sleep apnea in stroke survivors: what do we really know? Stroke 43:3118-3123, 2012

128. Turan TN, Cotsonis G, Lynn MJ, Chaturvedi S, Chimowitz M: Relationship between blood pressure and stroke recurrence in patients with intracranial arterial stenosis. Circulation 115:2969-2975, 2007

129. Ustrell X, Pellisé A: Cardiac workup of ischemic stroke. Curr Cardiol Rev 6:175-183, 2010

130. Wang Y, Wang Y, Zhao X, Liu L, Wang D, Wang C, et al: Clopidogrel with aspirin in acute minor stroke or transient ischemic attack. N Engl J Med 369:11-19, 2013

131. Wann LS, Curtis AB, Ellenbogen KA, Estes NA III, Ezekowitz MD, Jackman WM, et al: 2011 ACCF/AHA/HRS focused update on the management of patients with atrial fibrillation (update on Dabigatran): a report of the American College of Cardiology Foundation/American Heart Association Task Force on practice guidelines. Circulation 123:1144-1150, 2011

132. Wannamethee SG, Shaper AG, Whincup PH, Walker M: Smoking cessation and the risk of stroke in middle-aged men. JAMA 274:155-160, 1995

133. Webb AJ, Fischer U, Mehta Z, Rothwell PM: Effects of antihypertensive-drug class on interindividual variation in blood pressure and risk of stroke: a systematic review and meta-analysis. Lancet 375:906-915, 2010
134. White HD, Simes RJ, Anderson NE, Hankey GJ, Watson JD, Hunt D, et al: Pravastatin therapy and the risk of stroke. $\mathbf{N}$ Engl J Med 343:317-326, 2000

135. Wiviott SD, Braunwald E, McCabe CH, Montalescot G, Ruzyllo W, Gottlieb S, et al: Prasugrel versus clopidogrel in patients with acute coronary syndromes. N Engl J Med 357: 2001-2015, 2007

136. Wiysonge CS, Bradley H, Mayosi BM, Maroney R, Mbewu A, Opie LH, et al: Beta-blockers for hypertension. Cochrane Database Syst Rev (1):CD002003, 2007

137. Woodward M, Lam TH, Barzi F, Patel A, Gu D, Rodgers A, et al: Smoking, quitting, and the risk of cardiovascular disease among women and men in the Asia-Pacific region. Int J Epidemiol 34: 1036-1045, 2005

138. Xiao Q, Murphy RA, Houston DK, Harris TB, Chow WH, Park Y: Dietary and supplemental calcium intake and cardiovascular disease mortality: the National Institutes of HealthAARP diet and health study. JAMA Intern Med 173: 639-646, 2013

139. Yaggi HK, Concato J, Kernan WN, Lichtman JH, Brass LM, Mohsenin V: Obstructive sleep apnea as a risk factor for stroke and death. N Engl J Med 353:2034-2041, 2005

140. Yusuf S, Diener HC, Sacco RL, Cotton D, Ounpuu S, Lawton WA, et al: Telmisartan to prevent recurrent stroke and cardiovascular events. N Engl J Med 359:1225-1237, 2008

141. Yusuf S, Sleight P, Pogue J, Bosch J, Davies R, Dagenais G: Effects of an angiotensin-converting-enzyme inhibitor, ramipril, on cardiovascular events in high-risk patients. $\mathbf{N}$ Engl J Med 342:145-153, 2000

142. Zhang H, Thijs L, Staessen JA: Blood pressure lowering for primary and secondary prevention of stroke. Hypertension 48:187-195, 2006

Manuscript submitted September 13, 2013.

Accepted October 11, 2013.

Please include this information when citing this paper: DOI: 10.3171/2013.10.FOCUS13402.

Address correspondence to: Kelly D. Flemming, M.D., Mayo Clinic College of Medicine, Department of Neurology, W8B, 200 First St. SW, Rochester, MN 55905. email: flemming.kelly@mayo. edu. 